\title{
SOCIO-DEMOGRAPHIC COMPOSITION OF THE GEOGRAPHICALLY IMMOBILE URBAN POPULATION
}

\section{Dzīvesvietu nemainījušo pilsētas iedzīvotāju sociāli demogrāfiskais sastāvs}

\author{
Baiba Švāne \\ University of Latvia, Faculty of Geography and Earth Sciences \\ baiba.svane@gmail.com
}

\begin{abstract}
Most of the populace remains geographically immobile according to classical migration theories. An important consideration that limits change of place of residence is attachment to that place and its people, as well as some life-shaping circumstances such as job prospects, education, raising children and the buying of a residential property (Fischer et. al. 2000). More than half of the residents of Rigga (419146) in 2018 have lived in the same neighbourhood for at least 18 years (CSB 2018). This raises the question as to whether they also share common socio-economic circumstances. Geographically immobile residents are the core of the population. Study analyses on the socio-demographic background of geographically immobile residents of Rigga, who have not changed location since the 1990s, used data from a 2015 survey $(\mathrm{n}=867)$. The residential 'harbours' for long-term residents are Soviet socialist periodbuilt apartment-block housing neighbourhoods. Having a population of school-age children, people in retirement and/or on a low income might contribute to some of the reasons for staying at one place for longer periods of time in suburban Riga. The socio- demographic characteristics of the geographically immobile population displays differences among respondents residing in different neighbourhoods. Among the neighbourhoods with the highest share of geographically immobile respondents, the areas located on the outskirts of the capital city are less attractive than those more central and with higher incomes and children.
\end{abstract}

Keywords: geographical immobility, residential mobility, Rīga.

\section{Introduction}

Geographical immobility refers to a difficulty for people to move to different places of residence (Cambridge University Press 2011). Despite the fact that migration researchers usually concentrate on moving, most people remain geographically immobile (non-mobile). An important consideration that limits mobility is attachment to a place and its people (Fischer et al. 2000). Research studies on geographical immobility in Sweden show that the longer the period of time lived in the one place, the less the probability of moving away, because local knowledge and social ties that have developed over a period of time - insider advantages - might be lost in the event of changing place of residence (Fischer et al. 2000). On the other hand, at some stages of life, the decision to move is necessary to adjust for a new situation or circumstances (Figure 1).

Research studies on geographical immobility are often related to the labour market (e.g. Fischer et al. 2000; Green and Canny 2003), because an inability to move for work reasons may be a cause of unemployment. Financial issues may constrain geographical mobility between regions and countries despite wage differences, because of the costs of moving, variation in housing prices and in cost of living, all of which may be determinants of geographical immobility (Greenwood 1997; Fischer 
et al. 2000). Nevertheless, yet another decisive reason for residential stability may be the individual chosen career strategy. According to the research on work-directed relocation in England, people may choose to develop their career by change of employers and/or commuting patterns rather than by change of location, which may be on behalf of family members, or, a self-employed person who aims to become an entrepreneur using location specific benefits (Green and Canny 2003). Research on residential stability is important as the issue of geographical mobility and immobility contributes to temporal spatial inequalities through segregation, gentrification and the transmission of wealth (Coulter et al. 2013). A significant question in researches on geographical immobility is to do with housing policy and the availability of accommodations. Contrary to tenant-market dominant western European cities, many of the Central and Eastern European cities, after the mass privatisation of housing that took place in the 1990s, ended up with home owner dominated housing markets (Herfert et al. 2012). This specific feature of post-Soviet socialist countries - that a large number of dwellings are owned by inhabitants - contributes to geographical immobility (see Figure 1). Nowadays, a still high share of owner-occupied housing and the lack of public housing is a distinctive feature in Eastern and Central European cities (Kovacs and Herfert 2012).

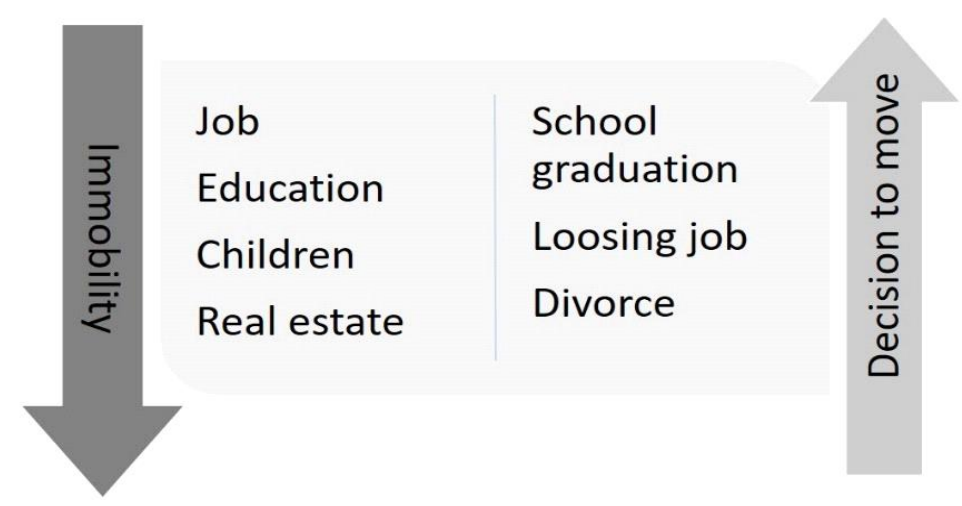

Figure 1. Contributing factors for geographical immobility and/or mobility (author's figure based on Fischer et al. 2000).

Previous studies on geographical immobility in Latvia have focussed on rural areas in the context of migration (Krišjāne et al. 2017). However, a large portion of residents in Riga are geographically immobile. More than half of the residents (419146) have lived in the same neighbourhood for at least 18 years (CSB 2018). At present, the neighbourhoods of Riga City that were built during the Soviet period of socialism are still home for almost three quarters (466394) of the City of Rìga population (CSB 2011). This raises the question as to whether the Soviet built neighbourhoods are 'harbours' of geographically immobile residents. Do they share common socio-demographic characteristics? The issue of geographically immobile residents in Rīga is an important area for research because numerous previous researches on Rīga and its surroundings focus more on the spatial mobility of its residents. Nevertheless, geographically 
immobile residents represent the core of the population. The aim of this study is to investigate the socio-demographic background of the geographically immobile residents of Rīga who have not changed their place of residence since the 1990s.

\section{Data and Methods}

The data used in this study was obtained from the 2015 Riga City Council survey among 2043 randomly (with quota elements) selected respondents in the age group 15-75 with face-to-face interviews on their own premises. The aim of the survey was to investigate levels of satisfaction with services available to residents of Rìga in addition to, and including, questions about residential satisfaction and the migration experience. The survey consisted of 84 questions in total. For this research project I used a sample of 867 residents who have remained in their current place of residence even since the 1990s. In order to analyse socio-demographic background descriptive statistics were used. In total, 10 variables were taken into consideration - gender, age group, language spoken, occupation, income level per person, family status, neighbourhood of residence, neighbourhood where working/studying, neighbourhood where spending leisure time, period of housing built and attitude towards Soviet period built neighbourhoods.

\section{The Population of Rīga}

The capital of Latvia is a shrinking city - between the population census of 2000 and that of 2011, Rìga has lost one sixth of its population, because of a trend of negative natural growth balance across Latvia and negative internal migration (CSB 2000; CSB 2011). Previous researches on the question of geographical mobility in Riga indicate that the inner city has lost residents more rapidly than other parts of the city and thus the share of residents living in neighbourhoods built during the period of Soviet socialism have grown (Krišjāne and Bērziņš 2014). The population Census of 2011 reveals that majority of the population 93\% (601314) lives in large scale housing estates (consisting of more than 30 dwellings), but also that a large part - 72\% (466394) lives in Soviet period built residences (CSB 2011). A similar number - 71\% (462721) of residents live in housing that is owned by a member of their household (CSB 2011). These geographically immobile residents are concentrated in neighbourhoods where Soviet period built apartment-block housing is dominant e.g. Vecmīlgrāvis, Imanta, Pḷavnieki, Bolderāja, Ziepniekkalns, Purvciems, Ķengarags and Zolitūde, according to the statistics (from 2000 and also from 2018) on internal mobility in Rīga (CSB 2018). Furthermore, the highest share of geographically immobile residents in neighbourhood areas is to be found in the periphery of the capital (Figure 2). 


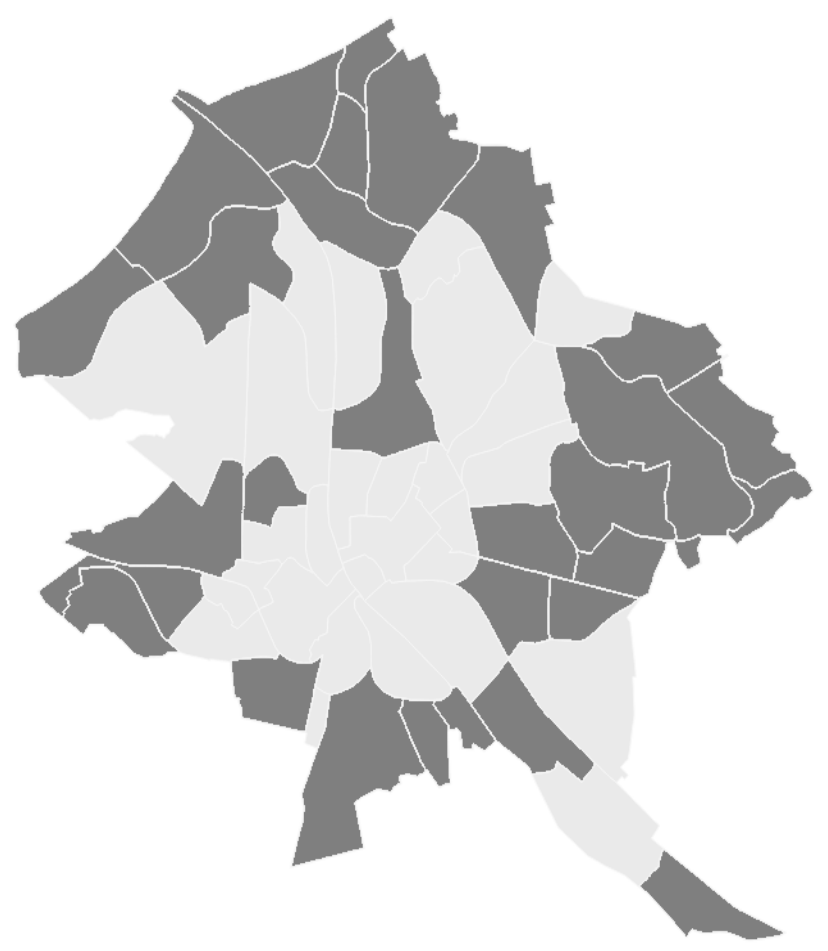

Figure 2. The neighbourhoods of Rīga with the highest share of geographically immobile residents (author's figure based on CSB 2018)

\section{Background of Geographical Immobility}

The results of this research study reveal that most of the geographically immobile respondents $(80 \%)$ live in Soviet period built housing. Moreover, neighbourhoods of large scale housing estates have a good image in the opinions of most respondents $(79 \%)$ and they are quite likely to spend their leisure time in the neighbourhood where they live. At the same time only less than half $(37 \%)$ of the respondents work or study in the local neighbourhood, which tells us that there might be other reasons for keeping the same residence for so long a time even if it is not close to work or school. Another geographical immobility contributing factor might be that of having children in the family, because almost one third of respondents (29\%) have school-age children. Also, one third of respondents are now at retirement age, which might be a contributing factor for their choice to stay at their residences for a longer period of time (Table 1). The distribution between age groups and the ethnic division of long-term respondents seems even. 
Table 1. Socio-demographic characteristics of geographically immobile respondents (\%) $(\mathbf{n}=867)$

\begin{tabular}{|l|c|}
\hline Age group & \% \\
\hline $25-34$ & 20 \\
$35-44$ & 16 \\
$45-54$ & 19 \\
$55-64$ & 22 \\
$65-75$ & 23 \\
\hline Sex & \% \\
\hline Female & 61 \\
Male & 39 \\
\hline Occupation & $\%$ \\
\hline Unemployed & 7 \\
Employed & 66 \\
Retired & 27 \\
Studying & 1 \\
\hline Language spoken & $\%$ \\
\hline Latvian & 46 \\
Russian & 54 \\
\hline
\end{tabular}

When looking at geographically immobile respondents by neighbourhood the socio- demographic characteristics reveal differences among respondents residing in the various different neighbourhoods. Among the neighbourhoods with the highest share of geographically immobile respondents the neighbourhood areas located in the outskirts of the capital are less attractive to those suburbs with higher incomes and children than the more centrally located ones. In the periphery of the capital city, in Vecmīlgrāvis neighbourhood, more than two thirds of respondents are with low income; almost one third is in retirement and most of these households have no children. As opposite situation is to be observed in the more centrally located suburb of Kengarags where more than half of the respondents are with middle or high income and a significant portion have school-age children (38\%). The reason why Kengarags has attracted those with higher incomes and children might be a result of the closeness and good connection with public transport to the city centre - the centre of finance and of work places and where there is a concentration educational institutions.

\section{Conclusion}

In Rīga City, the population has been declining over the past several decades. Especially evident de-population is to be observed in the central area of the city. Residential housing has been replaced by hotels and offices and its residents have been replaced by tourists in the inner city - the centre of business with a rich historical heritage. Meanwhile, the residential population has been more stable in the peripheral areas of the capital. Studies show that neighbourhoods on the outskirts of the city, 
which consist of pre-dominantly Soviet socialist period-built apartment-block housing, are characterized by a high proportion of long-term residents. The specific feature of the Soviet socialist period-built apartment-block housing is that most actual residing tenants in the 1990s became home owners after the massive privatisation of previously state owned dwellings, and it is significant that this has contributed to residential stability.

The findings of this study suggest that such factors as family status, occupational status and income level are also important in shaping the distribution of the geographically immobile population in Rīga by neighbourhoods and not by gender, ethnicity or age group which is mostly similar in extent within all of the populace.

These findings can further be explained with the fact that having school-age children or being of retirement status and/or having a lower income level might contribute to the decision of staying at one place for a longer period of time in certain neighbourhoods of Riga. The neighbourhood areas located in the outskirts of the capital are less attractive than the more central to those with higher incomes and children.

The findings indicate that the major 'harbours" for long-term residents are the Soviet socialist period-built apartment-block housing neighbourhoods (e.g. Vecmīlgrāvis, Imanta, Pḷavnieki, Bolderāja, Ziepniekkalns, Purvciems, K,engarags and Zolitūde). These neighbourhoods have a good image in the eyes of geographically immobile residents and they are more likely to spend their leisure hours in the neighbourhood where they live. At the same time only less than half of these residents either work or study in the local neighbourhood, which suggests that residents are more likely to change commuting patterns rather than the place of residence.

Further studies of the significance of different factors shaping the profile of the geographically immobile population would be worthwhile. In this case, a more detailed analysis could also be undertaken on the effect of housing policy and socioeconomic factors.

\section{Acknowledgement}

This study was supported by National Research Program Project N ${ }^{\circ}$.VPP-IZM2018/1-0015.

\section{Kopsavilkums}

Lielākā dạ̣a cilvēku nekur nepārceḷas un uzskatāmi par geogrāfiski nemobiliem saskaņā ar migrācijas teorijām. Nozīmīgs iemesls, kas ierobežo pārcelšanos, ir piesaiste vietai un cilvēkiem un dzīves notikumi, piemēram, darbs, mācības, bērna piedzimšana un īpašuma iegāde (Fischer et al. 2000). Vairāk nekā puse Rīgas iedzīvotāju (419146) 2018. gadā dzīvoja tai pašā vietā, kur pirms 18 gadiem (CSB 2018). Tas rada jautājumu, vai šiem nemobilajiem iedzīvotājiem ir līdz̄̄gs sociālekonomiskais raksturojums? Nemobilie rīdzinieki ir nozīmīgs pētījuma objekts, jo vairāki iepriekšējie pētījumi par Rīgu un tās aglomerāciju fokusējās uz iedzīvotāju telpisko mobilitāti. Tomēr nemobilie rīdzinieki veido iedzīvotāju kodolu. Pētījumā, izmantojot 2015. gada aptaujas anketas datus ( $\mathrm{n}=867)$, analizēts to Rīgas iedzīvotāju sociālekonomiskais raksturojums, kuri nav pārcēlušies kopš 1990. gada. Ilgtermiṇa iedzīvotāji lielākoties apdzīvo padomju laikā būvētos mikrorajonus (Vecmīlgrāvi, Imantu, Pḷavniekus, Bolderāju, Ziepniekkalnu, 
Purvciemu, Ķengaragu un Zolitūdi). Dažādās apkaimēs dzīvojošo ilgtermina iedzīvotāju raksturojums atškiras. Vecmīlgrāvja apkaime, kas atrodas Rīgas nomalē, ir mazāk pievilcīga iedzīvotājiem ar augstākiem ienākumiem un bērniem, nekā tuvāk centram esošais Ķengarags. Nepilngadīgi bērni, mājoklis īpašumā un zemi ienākumi ir nozīmīgi faktori nemobilitātei Rīgas apkaimē.

\section{References}

Cambridge University Press (2011). Cambridge Business English Dictionary. Cambridge: Cambridge University Press.

Central Statistical Bureau of Latvia (2000). Tautas skaitīšana 2000. http://data1.csb.gov.lv/pxweb/lv/iedz/iedz_tautassk__demogr_tsk2000/?tablelist=true\&rxid=d891949 2-06f0-4d91-86c7-72286caaa641 (15.01.2018)

Central Statistical Bureau of Latvia (2011). Tautas skaitǐšana 2011. http://data1.csb.gov.lv/pxweb/lv/iedz/iedz_tautassk__riga/?rxid=d8919492-06f0-4d91-86c772286 caaa641 (29.08.2018)

Central Statistical Bureau of Latvia (2018). Pastāvīgo iedz̄̄votāju skaita izmaiṇu iemesli statistiskajos reǵionos, republikas pilsētās, novados, novadu pilsētās, pagastos un Rīgas apkaimēs http://data1.csb.gov.lv/pxweb/lv/iedz/iedz_riga/RIG050.px/?rxid=d8919492-06f0-4d91-86c7-

72286 caaa641 (29.08.2018)

Coulter, R., van Ham, M. and Findlay, A. (2013). New directions for residential mobility research: Linking lives through time and space. Discussion paper 7525. Bonn: Institute for the Study of Labour, 25.

Fischer, P.A., Holm, E., Malmberg, G. and Straubhaar, T. (2000). Why do people stay? Insider advantages and immobility. HWWA Discussion Paper, 112.

Green, A.E. and Canny, A. (2003). Geographical mobility: Family impacts. Bristol, The Policy Press, 60.

Greenwood, M.J. (1997). Internal migration in developed countries. Handbook of Population and Family Economics, 12 (1B), 647-720.

Herfert, G., Neugebauer, C.S., Smigiel, C. (2012). Living in Residential Satisfaction? Insights from Large-Scale Housing Estates in Central and Eastern Europe. Tijdschrift voor economische en sociale geografie, 104 (1), 57-74.

Kitching, R. (1990). Migration behaviour among the unemployed and low-skilled. In: Johnson, J.H. and Salt, J. (eds.) Labour migration. London: David Fulton, 172-190.

Kovacs, Z. and Herfert, G. (2012). Development pathways of large housing estates in postsocialist cities: An international comparison. Housing Studies, 27 (3), 324-342.

Krišjāne, Z. and Bērziņš, M. (2014). Intra-urban residential differentiation in the post-Soviet city: the case of Riga, Latvia. Hungarian Geographical Bulletin, 63 (3), 235-253.

Krišjāne, Z., Apsīte-Beriṇa, E., Bērziņš, M., Grīne, I. (2017). Regional topicalities in Latvia: mobility and immobility in the countryside. Proceedings of the 2017 International Conference “Economic Science for Rural Development”, 45, 127-133. 